\title{
Schottky diodes based on the zinc selenide semiconductor crystals
}

\author{
E.Voronkin \\ Institute for Scintillation Materials, STC "Institute for Single Crystals", \\ National Academy of Sciences of Ukraine, \\ 60 Lenin Ave., 61001 Kharkiv, Ukraine
}

Received April 21, 2013

The problems of raw materials obtaining for UV detectors such as crystalline elements based on zinc selenide ( $\mathrm{ZnSe}$ ) have been discussed. Electrical parameters of these elements have been determined. Method of Schottky diodes based on ZnSe manufacturing with various metal contacts $(\mathrm{Ni}, \mathrm{Pt}, \mathrm{Pd}, \mathrm{Al})$ has been presented. From the current-voltage characteristics of these diodes their main characteristics have been identified: range of work, dark currents and range of light sensitivity. The comparative characteristics of the diodes have been shown. It was defined that sensitivity of the diodes with platinum contacts under ultraviolet radiation exposure in 2-3 times higher than of the diodes that have contacts from nickel and palladium. The spectral characteristics confirm the efficiency of using the Schottky diodes on the base of $\mathrm{A}_{2} \mathrm{~B}_{6}$ semiconductors, particularly $\mathrm{ZnSe}$, for detection of ultraviolet radiation.

Рассмотрены проблемы получения сырья для УФ детекторов - кристаллических элементов на основе селенида цинка $(\mathrm{ZnSe})$. Определены электрические параметры данных элементов. Разработан способ производства диодов Шоттки на основе ZnSe c разичными металлическими контактами ( $\mathrm{Ni}, \mathrm{Pt}, \mathrm{Pd}, \mathrm{Al})$. Из вольт-амперных характеристик данных диодов определены их основные параметры: диапазон работы, темновые токи, диапазон изменения световой чувствительности. Представлены сравнительные характеристики полученных диодов. Показано, что чувствительность диодов с платиновыми контактами при облучении ультрафиолетовым излучением в 2-3 раза выше, чем у диодов с контактами из никеля и палладия. Спектральные характеристики подтверждают возможность использования диодов Шоттки на основе полупроводников $\mathrm{A}_{2} \mathrm{~B}_{6}$, в частности $\mathrm{ZnSe}$, для регистрации ультрафиолетового излучения.

Діоди Шотткі на основі напівпровідникових кристалів селеніду иинку. Є.Ф.Воронкін.

Розглянуто проблеми отримання сировини для УФ детекторів - кристалічних елементів на основі селеніду цинку ( $\mathrm{nnSe}$ ). Визначено електричні параметри даних елементів. Розроблено спосіб виробництва діодів Шотткі на основі ZnSe з різними металевими контактами ( $\mathrm{Ni}, \mathrm{Pt}, \mathrm{Pd}, \mathrm{Al}) .3$ вольт-амперних характеристик даних діодів визначено їх основні параметри: діапазон роботи, темнові струми, діапазон світлової чутливості. Представлено порівняльні характеристики отриманих діодів. Показано, що чутливість діодів з платиновими контактами при опроміненні ультрафіолетовим випромінюванням в 2-3 рази вище, ніж у діодів з контактами з нікелю і паладію. Спектральні характеристики підтверджують можливість використання діодів Шотткі на основі напівпровідників $\mathrm{A}_{2} \mathrm{~B}_{6}$, зокрема $\mathrm{ZnSe}$, для реєстрації ультрафіолетового випромінювання. 


\section{Introduction}

Semiconductor materials with a band gap $\left(\varepsilon_{g}\right)$ from 2.5 to $3.5 \mathrm{eV}$ and high concentration of the charge carriers widely used for photoelectric detection of ultraviolet (UV) radiation. These demands are satisfied by a number of semiconductor compounds of $A_{3} B_{5}$ and $A_{2} B_{6}$ group. For example, silicon photodetectors have the highest sensitivity in the visible and infrared regions of the spectrum. Gallium phosphide possesses high sensitivity in the far UV region, but has low sensitivity in the short UV range. Silicon carbide has short region of sensitivity in the range of $200-400 \mathrm{~nm}$. Gallium nitride shows good detection characteristics in the UV part of the spectrum, but has not been widely used because of the high production expenses.

One of the most promising materials for photovoltaic UV detectors is zinc selenide (ZnSe). The technology of ZnSe crystals production is quite mastered. Also there is a possibility of obtaining ZnSe crystals with high and low resistance which is allowing us creation of the diodes detectors for different frequency bands with preset sensitivity. Schottky diodes based on ZnSe possess wide range of sensitivity in the ultraviolet part of the spectrum and in combination with filters give us a possibility of selective UV photodetectors creation. The diode parameters are highly dependent on physical properties of the semiconductor substrate, on quality of barrier layer, on resistance level of the contacts, on the detector's design and technological features of its production.

The surface potential barrier on the metal-semiconductor border ensures effective separation of the charge carriers that have been generated near the barrier as a result of the photons radiation absorption. Mechanisms of radiation absorption by such surface-barrier diodes have been studied by many authors [1-4]. In this work the basic characteristics and the experimentally measured parameters of Schottky photodiodes based on $\mathrm{ZnSe}$ with metal contacts $(\mathrm{Ni}, \mathrm{Pt}, \mathrm{Pd})$ are presented. Also their spectral sensitivity characteristics have been examined.

\section{Experimental}

The photodiodes was made from zinc selenide. Undoped ZnSe crystals usually have electrical resistivity at the level of $10^{10_{-}}$ $10^{11} \mathrm{Ohm} \cdot \mathrm{cm}$ which is close to the materials - insulators. To provide the necessary elec- trical parameters of semiconductor substrate the doping of crystals by donor impurities was used. In this case electrical resistivity of the crystal has been decreased to $10^{6} \mathrm{Ohm} \cdot \mathrm{cm}$. After annealing at $1300 \mathrm{~K}$ the ZnSe-Te crystals electrical resistivity decreases to $100-200 \mathrm{Ohm} \cdot \mathrm{cm}$, which is quite acceptable for production of Schottky diodes.

The single crystals have been sawed on smaller crystal elements $4 \times 4 \times 1 \mathrm{~mm}^{3}$ in size. For chemical etching and polishing of semiconductor compounds of $A_{2} B_{6}$ group it is widely in use bromine-methanol etchant which provides satisfactory surface quality for these compounds. Surface etching process of the crystal is determined by concentration of bromine in the alcohol solution and by kinetics of the oxidation of selenium. Typically etching rate in $10 \%$ solution of bromine was $5-10 \mu / \mathrm{min}$.

Another option of the surface polishing may be etching process with usage of chromic anhydride $\left(\mathrm{CrO}_{3}\right)$ in solution of perchloric acid. The etching speed in solution of $12 \mathrm{~g}$ of $\mathrm{CrO}_{3}$ (anhydrous) and $30 \mathrm{ml}$ of $\mathrm{HCl}$ (concentrated) at $315 \mathrm{~K}$ temperature was $1-2 \mu / \mathrm{min}$. The surface of the samples was like a mirror with no visible holes or defects. The lower etch rate allows more precise control of the chemical polishing process.

After etching the samples were washed in distilled water and then dried at temperature of $50-70^{\circ} \mathrm{C}$ for $10-15 \mathrm{~min}$. In developing of the optimal conditions for the surface preparation of ZnSe crystals for covering by metal layer it was found the positive effect of annealing of the samples in stream of hydrogen at the temperature of 420-450 K. Thus the samples should preferably as fast as possible be used for coating of the barrier layer and contacts to prevent surface oxidation. After drying they are immediately placed in a vacuum system (vacuum was $10^{-5} \mathrm{~mm} \mathrm{Hg}$ ) for metal contacts deposition ( $\mathrm{Ni}, \mathrm{Pt}$ or $\mathrm{Pd})$. The metal's quantity for contacts spraying was chosen with taking into account of the necessity to obtain the similar thickness of the sprayed layer. Configuration and sizes of photosensitive areas were selected with the expectation to leave side surface of the crystal free from impurities. The contact to the semitransparent film of $\mathrm{Ni}$ or other contact metal was formed by the thick layer of indium on perimeter of the crystal through a mask so as not to touch the lateral sides of 
the crystal. The effective area of the photodiodes was slightly less than physical dimensions of the semiconductor crystals. On the back surface of the semiconductor a contact layer of indium was deposited.

Height of the potential barrier of the semiconductor's space charge after metal deposition depends on the semiconductor parameters $(n, \varepsilon)$, dielectric properties of the gap, surface electron states of the contacts and the contact potential difference.

In experiments with diode's optoelectronic characteristics measurements a lamp DRH-250 was used. Optical power was changing by variation of distance between the emitter and the photodetector and was calculated accordingly. Measurements of current-voltage characteristics (CVC) and capacitance of UV sensors based on $\mathrm{ZnSe}(\mathrm{Te})$ crystals were carried out by the following equipment: voltmeter V7-40, power supply B5-47, electrometric amplifier U5-11 and digital LCR-meter E7-12. Optical measurements were made by the original microprocessor-aided apparatus for photodetector's parameters determination. This apparatus allowed us recalculating the incident radiation power which falls on the diode surface as a function of the distance between radiation source and photodiode. The focus was on the diodes characteristics in the reverse engaging when the diode operates in the photodiode mode.

\section{Results and discussion}

Measured dark characteristics of all three metal contacts $(\mathrm{Pd}, \mathrm{Pt}$ and $\mathrm{Ni})$ are close to the range of reverse voltages up to $6 \mathrm{~V}$. Under higher voltage conditions in the diodes with platinum contact the sharp increase of reverse current begins that reaches hundreds of micro amps. Similar increase in the current in the diodes with nickel and palladium contacts occurs at voltage greater than $8 \mathrm{~V}$. The results of the experimental measurements for diodes with

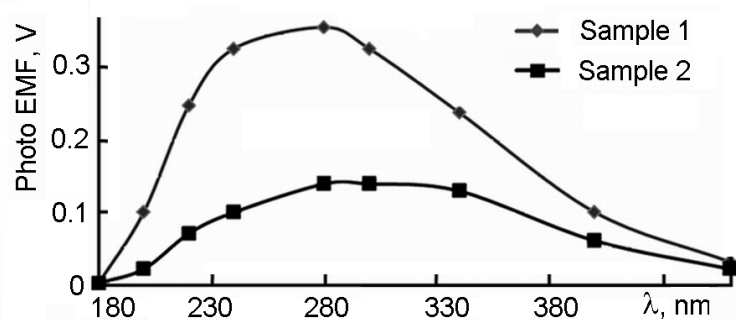

Fig. Spectral characteristics of the Ni-ZnSeIn samples of UV photodetectors.

various metal contacts can be found in Table (the reverse engaging). Barrier structures (Ni, Pt, Pd-ZnSe-In) had typical diode characteristic and were sensitive to UV radiation.

Under radiation and with increasing of the radiation power the photodiodes currents vary greatly. The greatest characteristics stability possesses the diodes with palladium contacts, but they also have the least sensitivity. The greatest currents and values of short-circuit currents have the platinum contacts diodes. Current sensitivity for these diodes in the wavelength range from 300 to $400 \mathrm{~nm}$ is $0.08-0.1 \mathrm{~A} /$ watt.

Spectral characteristics of the diodes were obtained with the use of SF-46 spectrophotometer. Spectral sensitivity range of the diodes was from 200 to $460 \mathrm{~nm}$. Results of the photovoltage measurements for two different samples are shown in Fig. Diodes $\mathrm{Ni}-\mathrm{ZnSe}-\mathrm{In}$ was made by the described above technology, but was taken from different parties.

Explanation of the experimental results is a very difficult task when from the total dependence we need to pick out the role of the certain mechanism that determines value of the current through device at these exposure conditions. The diode current-voltage characteristic is defined in the best case by participation of all generated by light charge carriers in the photocurrent forma-

Table. Results of the experimental measurements for diodes with different metal contacts

\begin{tabular}{|c|c|c|c|c|c|c|c|c||}
\hline$U, \mathrm{~B}$ & 0 & 2 & 4 & 6 & 8 & 10 & Contact & Lighting \\
\hline$I, \mathrm{mkA}$ & 0 & 1 & 2 & 4 & 8 & 18 & $\mathrm{Pd}$ & no \\
$I, \mathrm{mkA}$ & 0 & 1 & 1.5 & 4 & 12 & 20 & $\mathrm{Pt}$ & no \\
$I, \mathrm{mkA}$ & 0 & 1 & 2 & 6 & 18 & $\mathrm{Ni}$ & no & yes \\
$I, \mathrm{mkA}$ & 6 & 8 & 11 & 14 & 20 & 80 & $\mathrm{Pd}$ & yes \\
$I, \mathrm{mkA}$ & 18 & 43 & 68 & 140 & $\mathrm{Pt}$ & yes & & $\mathrm{Ni}$ \\
$I, \mathrm{mkA}$ & 5 & 22 & 25 & 30 & 55 & 97 & yi \\
\hline
\end{tabular}


tion. Collection coefficient of the charges (ratio of the number of electron-hole pairs separated by contact field to the number of pairs that appears as a result of radiation absorption) and internal quantum efficiency form significant part of the spectral response of the photodiode characterization. Therefore, the process of collecting the charge carriers and determination of their contribution to the CVC formation is no less important than the process of the charge carrier's generation. Therefore, the important parameters such as absorption coefficient of the semiconductor (that in large extent determines the spectral characteristics of the diodes), concentration of the charge carriers or relative resistivity of the semiconductor, lifetime of the nonbasic charge carriers, diffusion coefficient and design features of the photodiode are gaining significance.

Since ZnSe semiconductor has direct-gap transitions the optical absorption, particularly in the UV range quickly reaches the value in $10^{5}-10^{6} \mathrm{~cm}^{-1}$. This means that almost all of the radiation is absorbed at the contactarea which is only a few microns (at thickness of 3-5 $\mu \mathrm{m}$ the absorption is $90-95 \%)$. The spectral sensitivity range of the photodiode defines by the absorption coefficient and, if you created conditions for increasing the collection efficiency over the spectrum and all other conditions being unchanged, we should expect expansion of the photodiode spectrum sensitivity, as we observed in our case. The maximum of spectral sensitivity is in range from 260 to $280 \mathrm{~nm}$. In the majority of publications $[1,4]$ it was mentioned that the mechanism of charge transport in Schottky diodes was determined by thermionic emission and generation-recombination mechanisms in the depletion layer. The results of calculations of the currentvoltage characteristics using the Sah-NoyceShockley generation-recombination theory with taking into account the resistivity semiconductor and charge carrier mobility, the barrier height $(\varphi=1.2 \mathrm{eV})$ confirm the conclusion about the mechanism of current flow through the contact.

Creation of the resistivity contact for semiconductor with $n$-type conductivity ( $\mathrm{ZnSe})$ is a complicate task. In semiconductors $A_{2} B_{6}$ the surface state density is small and the resistivity contact can be obtained by usage of metal for which the electron work function $F_{m}$ is less than affini ty energy for $n$-type semiconductor. The resistivity contact can be made from In and alloy of $\mathrm{Ti}, \mathrm{Pt}$ and $\mathrm{Au}$ while it is necessary to pay attention to presence of the intermediate high-resistivity layer which may be present on the compound surface, but may be removed by heat treatment.

\section{Conclusions}

The technology of Schottky diodes production with different metal contacts (Pd, $\mathrm{Pt}$ and $\mathrm{Ni}$ ) has been developed. These Schottky diodes allow manufacturing the photodetectors with the characteristics required for the registration of UV radiation in range of $0.2-0.4 \mu \mathrm{m}$ with high sensitivity. The measurements results of the currentvoltage and spectral characteristics of the experimental samples of photodiodes have been presented.

\section{References}

1. T.V.Blank, Yu.A.Goldberg, Semiconductors, 37, 1025 (2003).

2. V.P.Makhno, V.Melnyk, Semiconductors, 29, 1468 (1995).

3. G.A.Ilchuk, V.Y.Rud, Y.V.Rud et al., Semiconductors, 34, 809 (2000).

4. V.L.Pereveytaylo, J.G.Dobrovolsky, V.M.Popov et al., Techn. and Design Electron. Equipm., No.2, 17 (2010).

5. Ukraine Patent No.42429 (2009). 